Portland State University

PDXScholar

Environmental Science and Management

Faculty Publications and Presentations

4-2015

\title{
Comparison of Fish Assemblages in Restored and Natural Mangrove Habitats Along an Urban Shoreline
}

Joseph R. Peters

Portland State University

Lauren A. Yeager

Florida International University

Craig A. Layman

Florida International University

Follow this and additional works at: https://pdxscholar.library.pdx.edu/esm_fac

Part of the Environmental Indicators and Impact Assessment Commons, Oceanography Commons, and the Water Resource Management Commons

Let us know how access to this document benefits you.

Citation Details

Peters, J. R., Yeager, L. A., \& Layman, C. A. (2015). Comparison of fish assemblages in restored and natural mangrove habitats along an urban shoreline. Bulletin of Marine Science, 91(2), 125-139.

This Article is brought to you for free and open access. It has been accepted for inclusion in Environmental Science and Management Faculty Publications and Presentations by an authorized administrator of PDXScholar. Please contact us if we can make this document more accessible: pdxscholar@pdx.edu. 


\section{Comparison of fish assemblages in restored and natural mangrove habitats along an urban shoreline}

\author{
${ }^{1}$ Marine Science Program, \\ Department of Biological \\ Sciences, Florida International \\ University, Miami, Florida 33199. \\ ${ }^{2}$ Present address: Department \\ of Environmental Science and \\ Management, Portland State \\ University, Portland, Oregon \\ 97201. \\ 3 Present address: National \\ Socio-Environmental Synthesis \\ Center, Annapolis, Maryland \\ 21401. \\ ${ }^{4}$ Present address: Department \\ of Applied Ecology, North \\ Carolina State University, \\ Raleigh, North Carolina 27695. \\ ${ }^{*}$ Corresponding author \\ email: <peters22@pdx.edu>, \\ telephone: (954) 205-4106.
}

Date Submitted: 11 September, 2014 Date Accepted: 12 February, 2015 Available Online: 4 March, 2015.

\author{
Joseph R Peters 1, 2 * \\ Lauren A Yeager ${ }^{1,3}$ \\ Craig A Layman ${ }^{1,4}$
}

\begin{abstract}
The installation of living shorelines is one strategy used to ameliorate habitat degradation along developed coastlines. In this process, existing hard structures, such as sea walls and riprap revetments, are supplemented with habitat forming species, e.g., oysters and mangrove trees, to improve habitat quality and function. Shoreline restorations in Biscayne Bay, Florida, USA, often utilize red mangroves, Rhizophora mangle (Linneaus, 1753), in addition to riprap revetments, to help stabilize the shoreline. This riprap-mangrove habitat provides structure for marine organisms to utilize and is believed to improve shoreline habitats in areas previously cleared of mangroves. We examined whether habitat provisioning was similar between restored mangrove habitat with the inclusion of riprap boulders and natural mangrove shorelines. We compared fish assemblages between natural mangrove and riprapmangrove habitats within two areas of northern Biscayne Bay. Fish community structure and certain benthic cover types varied between mangroves and riprap-mangrove habitats. Total fish abundance was greater in mangrove habitat, while taxonomic richness was highest in riprap-mangrove sites in the northern part of the bay. Our findings suggest that fish assemblages and community structure are different between these habitat types, although the geographic context may mediate the effect of habitat type. Therefore, it is likely that these restored mangroves provide different ecological services than unaltered mangrove shorelines.
\end{abstract}

Impacts from human development, storms, and sea level rise collectively threaten shoreline habitats (Chambers 1991, Jackson et al. 2001, Alongi 2002, Granek and Ruttenberg 2007). Many natural habitats protect shorelines from erosion due to wave energy, and degradation of these habitats may result in a loss of this important ecosystem service. Previous efforts to circumvent further erosion damage to degraded shorelines resulted in the construction of bulkheads, sea walls, and boulders called riprap in place of oyster reefs, mangroves, and other shoreline habitats (Pilkey and Wright 1988, Douglas and Pickel 1999, Bulleri and Chapman 2010, Layman et al. 2014). While these structures may help prevent further erosion, they do not necessarily provide the other ecosystem services found in shoreline habitats, such as nutrient 
cycling, carbon sequestration, and improvement of water quality (Grabowski and Peterson 2007, Scyphers et al. 2011). An emerging practice called "living shorelines" is used in restoration projects to improve the function and quality of altered shoreline habitats by supplementing existing hard structure with native organisms (Bacchiocchi and Airoldi 2003, Airoldi et al. 2005, Bulleri and Chapman 2010).

Ecologists and restoration practitioners are often interested in the comparison of altered and restored habitats relative to natural habitats to determine the efficacy of restoration design (Field 1998, Kentula 2000, Peterson et al. 2000, Lewis 2005, Fodrie et al. 2014). For example, oyster shells are frequently used to restore breakwater reefs and have been shown to improve numerous habitat functions over traditional sea walls (Peterson et al. 2003, Scyphers et al. 2011). When live oysters colonize these reefs, they improve water quality by removing contaminants and phytoplankton that have taken up excess nutrients (Grabowski and Peterson 2007, Kellogg et al. 2013). Therefore, the process of adding habitat forming species, such as oysters, to artificial shorelines may improve habitat quality and other ecosystem services.

In Biscayne Bay, a shallow subtropical lagoon on the southeastern coast of Florida, USA, mangrove habitat has declined by as much as $80 \%$ (Harlem 1979, Milano 1999, Serafy et al. 2003). Northern Biscayne Bay, surrounded by the highly urbanized metropolis of Miami, has lost an even greater percentage of its once mangrove-lined shoreline (Milano 1999, Serafy et al. 2003). In place of mangroves, vertical concrete sea walls and limestone boulders called riprap have been installed to reinforce shorelines. Restoration of mangroves is now a major component of shoreline protection projects (Milano 1999). Recent restoration designs have incorporated living shoreline practices by planting young mangrove seedlings shoreward of riprap (Milano et al. 2007). The existing riprap is used as a barrier to prevent shoreline erosion and absorb wave energy, thereby creating a low wave energy zone for mangrove propagules to grow.

Mangroves provide a myriad of ecosystem services such as improving water quality, trapping sediment and pollutants, and sequestering carbon (Moberg and Rönnbäck 2003). Mangrove prop roots are also critical habitat for fishes including juveniles of many coral reef fish species (Mumby et al. 2004, Faunce and Serafy 2006, Thayer et al. 2007, Nagelkerken et al. 2008). In light of the numerous services provided by natural mangrove habitat, comparisons of restored riprap-mangrove areas to natural mangrove shorelines would be useful in assessing the relative value of these living shorelines and inform future restoration projects.

In the present study, we examined if natural mangrove and restored riprap-mangrove habitats support different assemblages of fishes. Specifically, comparisons were made between these two habitat types with respect to fish abundances, taxonomic richness, and community structure. Composition of benthic substrate also was examined to provide additional information about differences in habitat structure among these sites. Additionally, we examined whether fish assemblages and benthic composition were affected by spatial context by comparing sites within two areas of the bay. 


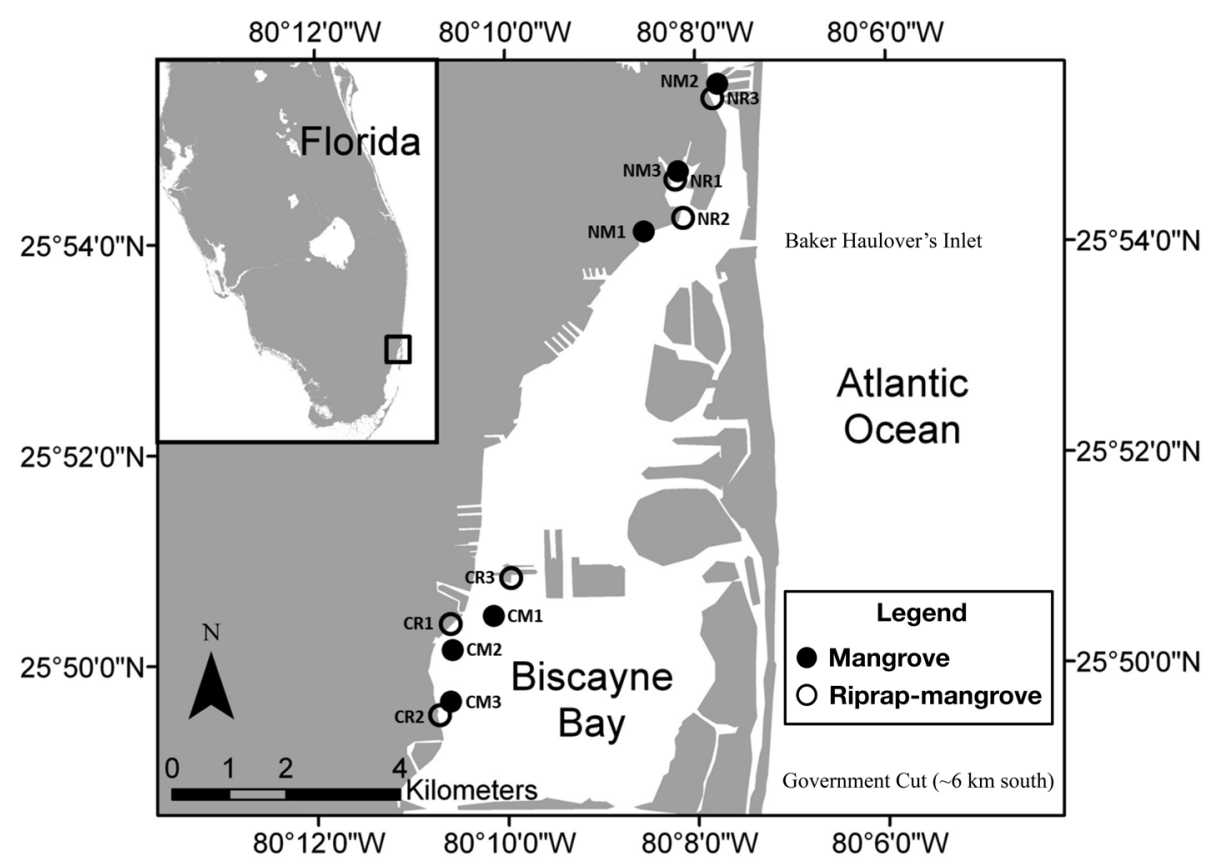

Figure 1. Study sites in northern Biscayne Bay. Bay area: $\mathrm{N}=$ north sites, $\mathrm{C}=$ central sites. Habitat type: $\mathrm{M}=$ mangrove, $\mathrm{R}$ = riprap-mangrove.

\section{Methods}

Study AREA.-The present study was conducted in northern Biscayne Bay, which occupies the area between Miami Beach and the Miami metropolitan area (Fig. 1). Two habitat types were surveyed: natural mangrove shorelines and mangroves shoreward of riprap revetments (henceforth called mangrove and riprap-mangrove, respectively; Fig. 2). Mangrove habitat was characterized primarily by the presence of red mangroves, Rhizophora mangle (Linneaus, 1753), with submerged prop-root structure. Riprap-mangrove habitat consisted of submerged boulders (approximately 0.30-1 m diameter) and some prop root structure with mangroves planted shoreward of the rock at the time of restoration. Sampling sites were selected based on the following criteria: (1) mangrove presence, either intact stretches or trees planted behind riprap; (2) water depth of $95-130 \mathrm{~cm}$ at low tide; and (3) at least $100 \mathrm{~m}$ separation between sites. Because mangrove habitat has been significantly reduced in Biscayne Bay, only 12 sites met these criteria and the sites were divided into two main areas of the bay, north and central (Online Appendix 1). All north sites were within approximately $3 \mathrm{~km}$ of Baker's Haulover Inlet, the northernmost pass of the Biscayne Bay lagoon. Central sites were located approximately $8 \mathrm{~km}$ south of Bakers Haulover Inlet and approximately $8 \mathrm{~km}$ north of Government Cut. Restoration sites were 10-15 yrs old, where the mangrove canopy heights ranged from about 2 to $5 \mathrm{~m}$. Intact mangrove canopy heights ranged from about 5 to $10 \mathrm{~m}$.

Fish Assemblages.-Fish assemblages were surveyed using a modified belt transect survey method (Serafy et al. 2003). This involved snorkeling along a $30 \times 2 \mathrm{~m}$ 

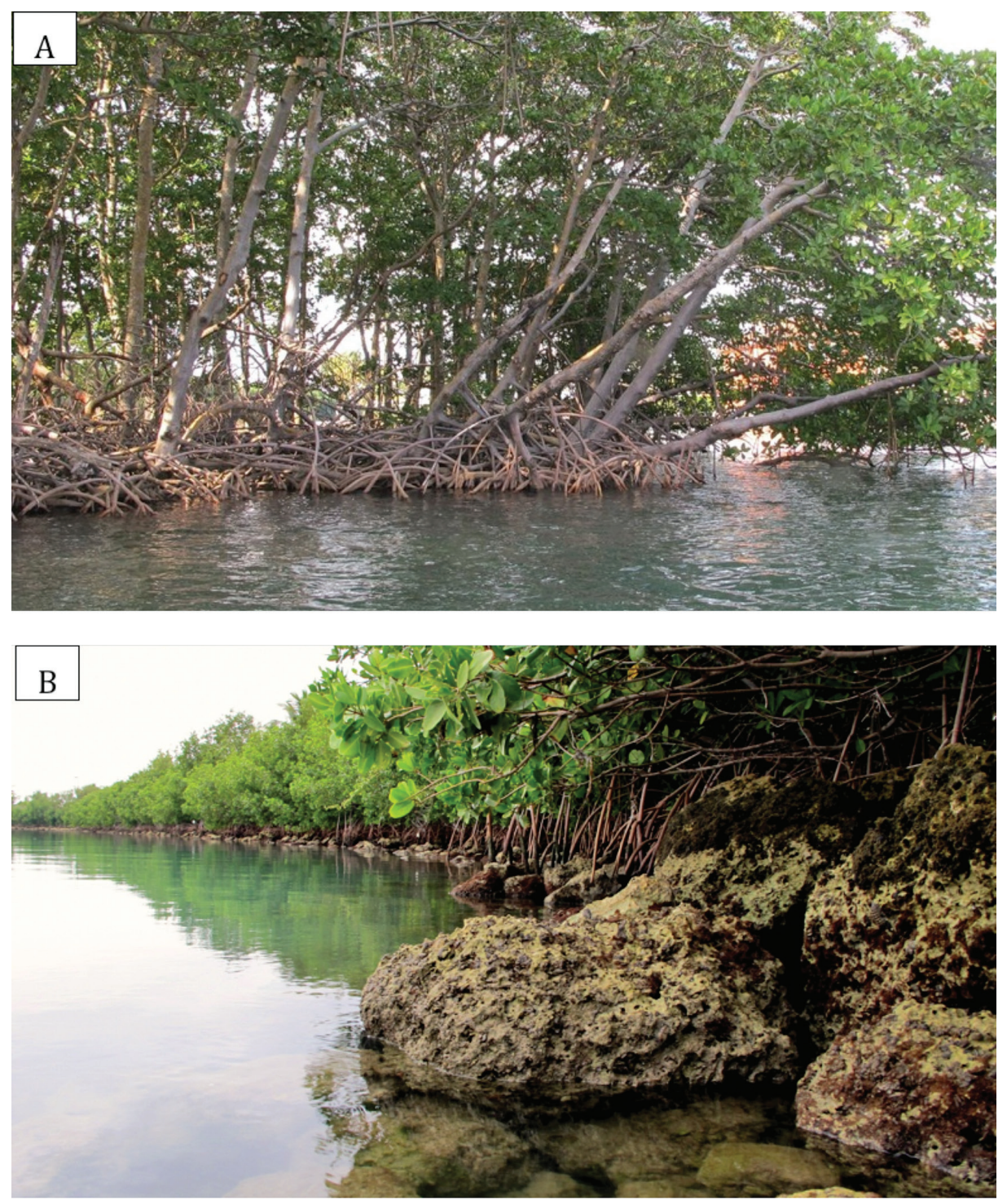

Figure 2. Examples of (A) natural mangrove and (B) riprap-mangrove shorelines.

transect running parallel to the shore and recording the identity and number of fishes. Abundances of individual species were estimated using numerical bins (e.g., 2-5 fish per transect, 6-10 fish per transect, etc.; see Online Appendix 2). We surveyed each site five times between September and November 2012. All surveys were conducted within 2 hrs of peak high tide. One transect survey was performed at each site on a sampling day. Fishes were identified according to Humann (1994). Individuals of related species with similar morphology that were difficult to identify were grouped into a single taxon at either the genus or family level (e.g., Scaridae, Haemulidae, and Clupeidae). Following Serafy et al. (2003), small, silvery, fork-tailed fishes 
commonly found inhabiting the water-column in large schools (i.e., Atherinopsidae and Clupeidae) were placed into one single group (small, water-column fishes, or SWC).

We used the midpoint of each fish abundance bin as our abundance estimate per transect for statistical analyses. Fish abundance then was averaged across all surveys to determine a mean abundance estimate for each species at each site. Total fish abundance was the summation of the species-specific mean abundance estimates at each site. We also compared the proportion of piscivores within the fish community between site and bay area to reveal if differences could be attributed to habitat type. We identified species as piscivorous based on diet information from Randall (1967) and Fishbase (Froese and Pauly 2000). Taxonomic richness at each site was calculated as the count of all unique taxa observed at a site across all five transects. We examined variation in total fish abundance (with and without SWC), the proportion of the community comprised of piscivores, and taxonomic richness as a function of habitat type or area of the bay with separate two-way analysis of variance (ANOVA) models (SPSS version 11.0).

We examined variation in fish community structure across sites based on a BrayCurtis similarity matrix of fish abundance. Prior to community structure analyses, the observed abundance of each species was summed across all five transects at each site. Abundances were then square-root transformed to down-weight the influence of most abundant taxa. We next employed a crossed, two-way analysis of similarity (ANOSIM) to determine if community structure differed significantly between habitat types and areas of the bay. Differences in community structure among sites were displayed graphically with a non-metric multidimensional scaling plot (nMDS). Upon finding differences in community structure between riprap-mangrove and mangrove habitats and areas of the bay, we used a percentage of similarity analyses (SIMPER) to determine which taxa contributed most to driving these differences. Analyses were conducted using Primer-E v.6 software (Clarke 1993).

Benthic Substrate Composition.-At each site, the percent cover of each benthic substrate type was estimated within 1- $\mathrm{m}^{2}$ quadrats using the Braun-Blanquet method (Braun-Blanquet 1932). In areas adjacent to the belt transect used in fish surveys (after the fish survey was complete), quadrats were thrown haphazardly with the condition that water depth was $95-130 \mathrm{~cm}$ at low tide. A total of five quadrats were surveyed at each site on a sampling day. Seagrass was identified to species, and macroalgae to genus following Littler et al. (1989) and Littler and Littler (2000). Sessile invertebrates were also enumerated in the quadrat and identified to phylum using Humann (1993). The areal coverage of each benthic type (e.g., sand or seagrass) was visually estimated to the nearest $5 \%$.

For statistical analyses, benthic cover types were classified into the following groups: sand, seagrass, macroalgae, cyanobacteria, macroinvertebrates, detritus, bare rock, and unconsolidated hard bottom. Percent covers of benthic types were averaged across all quadrats and survey dates at each site. A multivariate analysis of variance (MANOVA) was used to determine if there was an effect of habitat type, area of the bay, and their interaction on the mean coverage of all benthic types. Because the multivariate analysis indicated a significant habitat type $\times$ area interaction on benthic community composition (see Results), one-way ANOVAs were performed to examine effects on each individual cover category. 


\section{RESUlts}

Fish Assemblages.-In total, 42 taxa of fishes were identified in surveys, representing 28 families (Online Appendix 3). The most common fish families in mangroves were SWC fishes [i.e., Atherinopsidae (silversides), Clupeidae (herrings)] and Tetraodontidae (puffers), Lutjanidae (snappers), Sphyraenidae (barracudas), and juveniles of Haemulidae (grunts). In riprap-mangrove, the most abundant taxa were Tetraodontidae and juveniles of Gerridae (mojarra) and Sphyraenidae. Species composition differed between areas of the bay, with riprap-mangrove sites in north Biscayne Bay generally supporting more diverse communities characterized by juveniles of Haemulidae, Lutjanidae, Pomacentridae (damselfishes), Acanthuridae (surgeonfishes), and Scaridae (parrotfishes).

Mean total fish abundance differed between habitat types (ANOVA: $\mathrm{F}_{1,11}=280.6$, $P<0.001$ ), being higher in mangroves $\left[\right.$ mean $=47.0$ (SE 2.4) fish $\mathrm{m}^{-2}$ ] than in riprapmangrove habitats [8.0 (SE 2.9) fish $\mathrm{m}^{-2}$; Table 1, Fig. 3A]. Mean total fish abundance also differed between areas of Biscayne Bay $\left(\mathrm{F}_{1,11}=17.1, P=0.003\right)$, being higher in the north [32.0 (SE 8.2) fish $\mathrm{m}^{-2}$ ] than in the central bay [23.0 (SE 9.4) fish $\mathrm{m}^{-2}$. This pattern was driven primarily by the presence of SWC and when these fishes are excluded from analysis, fish abundance differed only by area of the bay $\left(\mathrm{F}_{1,11}=19.8, P=\right.$ 0.002 , Table 1), with mean abundance higher in the north [8.0 (SE 1.9) fish $\mathrm{m}^{-2}$ ] than in the central bay sites $\left[1.0\right.$ (SE 0.3) fish $\mathrm{m}^{-2}$, Fig. 3B]. There was an interaction between the effects of habitat type and area of the bay on the proportion of piscivorous fishes $\left(\mathrm{F}_{1,8}=18.5, P=0.003\right.$, Table 1$)$ with a higher proportion of piscivores in north

Table 1. Results from fish assemblage analyses of variance, including all factors and 2nd order interactions. Habitat type refers to riprap-mangrove vs mangrove sites; area refers to north or central Biscayne Bay. $P$-values $<0.05$ are shown in bold. SWC $=$ small water-column fishes.

\begin{tabular}{|c|c|c|c|c|}
\hline Dependent variables and factors & MS & $\mathrm{df}$ & $F$ & $P$ \\
\hline \multicolumn{5}{|l|}{ Mean total fish abundance } \\
\hline Habitat type & $5,739,217.5$ & 1 & 280.6 & $<0.001$ \\
\hline Area & $981,251.7$ & 1 & 17.1 & 0.003 \\
\hline Habitat type*area & $101,784.3$ & 1 & 1.8 & 0.200 \\
\hline Error & $57,501.3$ & 8 & & \\
\hline \multicolumn{5}{|l|}{ Mean fish abundance (without SWC) } \\
\hline Habitat type & $69,719.2$ & 1 & 2.4 & 0.200 \\
\hline Area & $577,011.2$ & 1 & 19.8 & 0.002 \\
\hline Habitat type*area & $116,018.6$ & 1 & 4.0 & 0.080 \\
\hline Error & $29,111.9$ & 8 & & \\
\hline \multicolumn{5}{|l|}{ Taxonomic richness } \\
\hline Habitat type & 60.8 & 1 & 2.2 & 0.200 \\
\hline Area & 630.8 & 1 & 23.0 & 0.001 \\
\hline Habitat type*area & 374.1 & 1 & 13.6 & 0.006 \\
\hline Error & 27.4 & 8 & & \\
\hline \multicolumn{5}{|l|}{ Proportion of piscivores } \\
\hline Habitat type & 272.2 & 1 & 6.3 & 0.040 \\
\hline Area & $1,862.5$ & 1 & 43.3 & $<0.001$ \\
\hline Habitat type*area & 794.6 & 1 & 18.5 & 0.003 \\
\hline Error & 43.0 & 8 & & \\
\hline
\end{tabular}



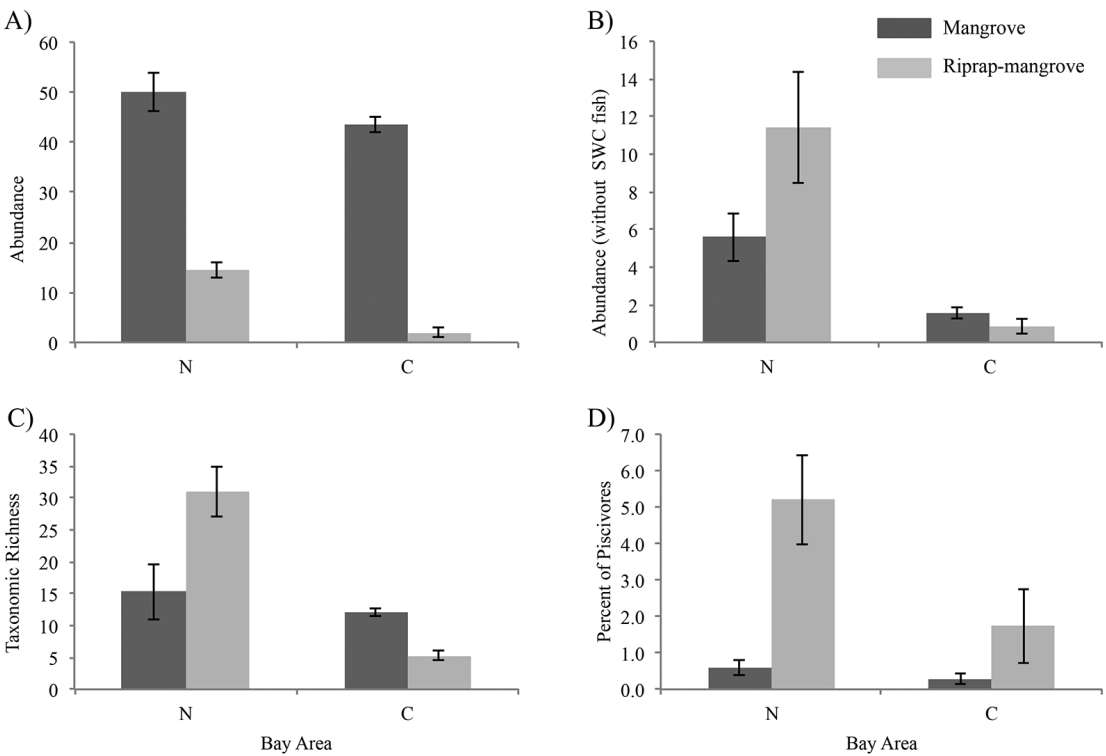

Figure 3. Effects of habitat type and area of Biscayne Bay on (A) total mean fish abundance per $\mathrm{m}^{2}$, (B) mean fish abundance per $\mathrm{m}^{2}$ (without small water-column fishes, SWC), (C) taxonomic richness and, (D) the percent of total fish abundance represented by piscivorous fishes. Error bars reflect the standard error (SE) of the mean value. Bay area: $\mathrm{N}=$ north sites, $\mathrm{C}=$ central sites.

riprap-mangrove sites [mean proportion $=5.2 \%$ (SE 1.2\%), Fig. 3D] relative to central riprap-mangrove $[1.7 \%(\mathrm{SE} 1.0 \%)]$ and mangrove sites $[$ north $=0.6 \%(\mathrm{SE} 0.21 \%)$, central $=0.3 \%(\mathrm{SE} 0.15 \%)]$.

Effects of habitat type on taxonomic richness varied between areas of the bay (habitat type $\times$ area interaction, ANOVA: $F_{1,11}=13.6, P=0.006$, Table 1, Fig. 3C). Taxonomic richness was greater in northern riprap-mangrove sites [31.0 (SE 0.1) taxa per site] compared to riprap-mangrove sites in the central bay [5.3 (SE 0.02) taxa per site]. Mangroves had a similar number of taxa regardless of location within the bay. One northern mangrove site (NM3) had high taxonomic richness ( $n=24$ taxa) compared to all of the other mangrove sites [mean $=13.0$ (SE 0.04) taxa per site]. This site had fishes of families not observed at other mangrove sites (e.g., Acanthuridae, Scaridae, see Online Appendix 3), although these were observed in the nearby riprap-mangrove site, NR1.

There were differences in fish community structure between riprap-mangrove and mangrove habitats and between areas of the bay (ANOSIM: $R=0.981, P=0.01$; and $R$ $=0.667, P=0.02$, respectively; Fig. 4). Similar to the pattern observed for taxonomic richness at mangrove sites, fish assemblages in mangroves were generally similar between north and central sites (mean similarity 79.17\%), and were dominated by SWC. In contrast, riprap-mangrove communities within different areas of the bay were less similar (mean similarity 59.39\%). Eucinostomus melanopterus (Bleeker, 1863) (flagfin mojarra) and species of juvenile Haemulid were the dominant taxa driving differences between the two regions. Haemulids were absent from surveys in the central riprap-mangrove sites, but were the most abundant fishes in north riprap-mangrove. 


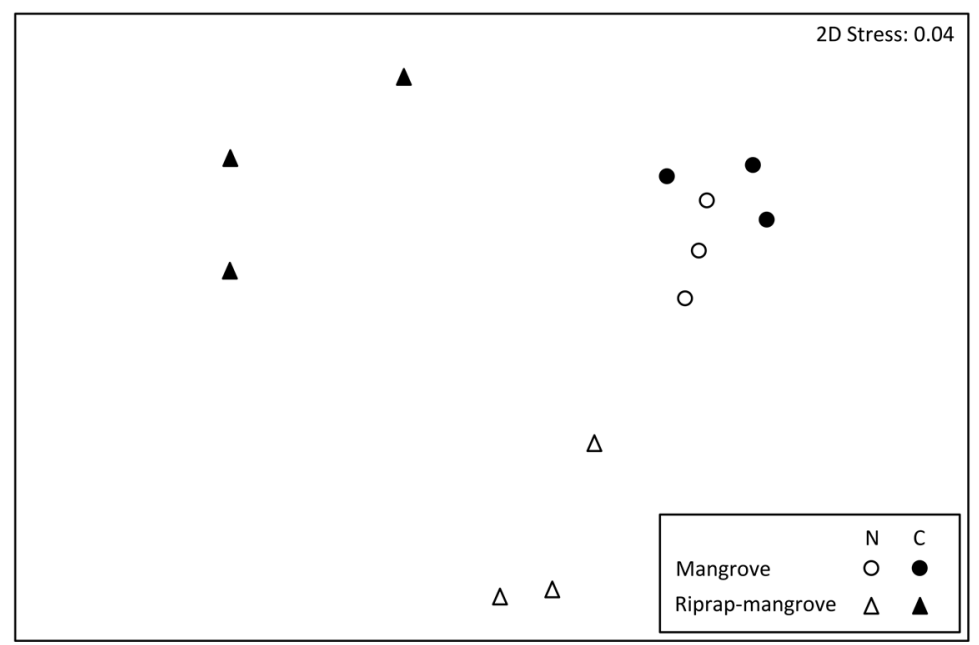

Figure 4. Non-metric Multidimensional Scaling plot (nMDS) of community structure across habitat types and areas of Biscayne Bay. Bay Area: $\mathrm{N}=$ north sites, $\mathrm{C}=$ central sites. Habitat type: Circles $=$ mangrove, Triangles $=$ riprap-mangrove . Each point represents the summed (across all five transects) community for each site.

Eucinostomus melanopterus made up a large portion of the fish community in central riprap-mangrove sites.

Benthic Substrate Composition.-Overall, the percent cover of benthic types varied between habitat types (MANOVA: $\mathrm{F}_{7,2}=523.5$, Wilks' $\lambda=0.0005, P=0.002$ ) and areas of the bay $\left(\mathrm{F}_{7,2}=144.8\right.$, Wilks' $\lambda=0.002, P=0.007$; Fig. 5). Sessile macroinvertebrate cover (e.g., tunicates, sponges, and coral) was greater in riprap-mangrove than in mangroves $\left(\mathrm{F}_{1,11}=13.5, P=0.006\right.$, Table 2$)$. There was a marginal difference in detritus cover among habitat types $\left(\mathrm{F}_{1,11}=5.1, P=0.05\right.$, Table 2$)$. Detritus cover was higher in mangroves in the north; however, one riprap-mangrove site in the central bay had high detritus cover. Cyanobacteria cover was higher in mangroves than in riprap-mangrove sites $\left(\mathrm{F}_{1,11}=11.34, P=0.001\right.$, Table 2). Macroalgae (e.g., Laurencia and Batophora spp.) cover was higher in riprap-mangrove than in mangroves $\left(\mathrm{F}_{1,11}=\right.$ 27.01, $P=0.0008$, Table 2).

\section{DISCUSSION}

We found differences in fish communities associated with natural mangrove and riprap-mangrove shorelines, likely attributable to differences in habitat structure. While we hypothesized that fish assemblages would differ between mangroves and riprap-mangrove habitats, we did not expect that riprap-mangrove habitats would contain the most species-rich fish communities. We found that northern riprapmangrove sites had the highest taxonomic richness and mean fish abundance (without SWC) relative to the locations in the central bay. We suspect that the reason for this trend is due to two factors: (1) differences in preference of habitat by some species; and (2) the proximity of the north sites to the ocean inlet.

Restoration projects that add hard structure to restore sedimentary shorelines may change fundamental properties of the habitat (Able et al. 1998, Bulleri and Chapman 
Table 2. Results from benthic substrata analyses of variance, including all factors and 2nd order interactions. Habitat type refers to riprap-mangrove vs mangrove sites; area refers to north or central Biscayne Bay. $P$-values $<0.05$ are shown in bold.

\begin{tabular}{|c|c|c|c|c|}
\hline Dependent variable and factor & MS & $\mathrm{df}$ & $F$ & $P$ \\
\hline \multicolumn{5}{|l|}{ Macroalgae } \\
\hline Habitat type & $5,501.9$ & 1 & 27.0 & 0.001 \\
\hline Area & 25.4 & 1 & 0.1 & 0.700 \\
\hline Habitat type*area & 0.5 & 1 & 0.0 & 1.000 \\
\hline Error & $1,629.8$ & 8 & & \\
\hline \multicolumn{5}{|l|}{ Seagrass } \\
\hline Habitat type & 23.9 & 1 & 7.0 & 0.030 \\
\hline Area & 9.8 & 1 & 2.9 & 0.100 \\
\hline Habitat type*area & 3.6 & 1 & 1.1 & 0.300 \\
\hline Error & 3.4 & 8 & & \\
\hline \multicolumn{5}{|l|}{ Cyanobacteria } \\
\hline Habitat type & 43.5 & 1 & 27.0 & 0.010 \\
\hline Area & 6.8 & 1 & 1.8 & 0.200 \\
\hline Habitat type*area & 12.7 & 1 & 3.3 & 0.100 \\
\hline Error & 3.8 & 8 & & \\
\hline \multicolumn{5}{|l|}{ Macroinvertebrate } \\
\hline Habitat type & 129.7 & 1 & 13.5 & 0.006 \\
\hline Area & 46.2 & 1 & 4.8 & 0.060 \\
\hline Habitat type*area & 6.7 & 1 & 0.7 & 0.400 \\
\hline Error & 9.6 & 8 & & \\
\hline \multicolumn{5}{|l|}{ Detritus } \\
\hline Habitat type & $1,851.3$ & 1 & 5.1 & 0.001 \\
\hline Area & 539.4 & 1 & 1.5 & 0.700 \\
\hline Habitat type*area & $2,311.6$ & 1 & 6.4 & 1.000 \\
\hline Error & 363.3 & 8 & & \\
\hline \multicolumn{5}{|l|}{ Sand } \\
\hline Habitat type & $4,792.0$ & 1 & 87.1 & $<0.001$ \\
\hline Area & $3,383.5$ & 1 & 61.5 & $<0.001$ \\
\hline Habitat type*area & $3,340.0$ & 1 & 60.7 & $<0.001$ \\
\hline Error & 55.0 & 8 & & \\
\hline \multicolumn{5}{|l|}{ Bare Rock } \\
\hline Habitat type & $2,146.7$ & 1 & 44.0 & $<0.001$ \\
\hline Area & 3.5 & 1 & 0.1 & 0.800 \\
\hline Habitat type*area & 3.5 & 1 & 0.1 & 0.800 \\
\hline Error & 48.8 & 8 & & \\
\hline \multicolumn{5}{|l|}{ Unconsolidated hard-bottom } \\
\hline Habitat type & 66.5 & 1 & 0.3 & 0.600 \\
\hline Area & 650.5 & 1 & 2.8 & 0.100 \\
\hline Habitat type*area & 64.2 & 1 & 0.3 & 0.600 \\
\hline Error & 236.2 & 8 & & \\
\hline
\end{tabular}

2010). Mangrove habitats are usually found along gently sloped shorelines with submerged prop roots providing wide expanse of submerged physical structure, often spanning tens of meters in breadth (Odum et al. 1982). Mangrove prop roots create large cavities of open interstitial space, which could allow unrestricted movement 


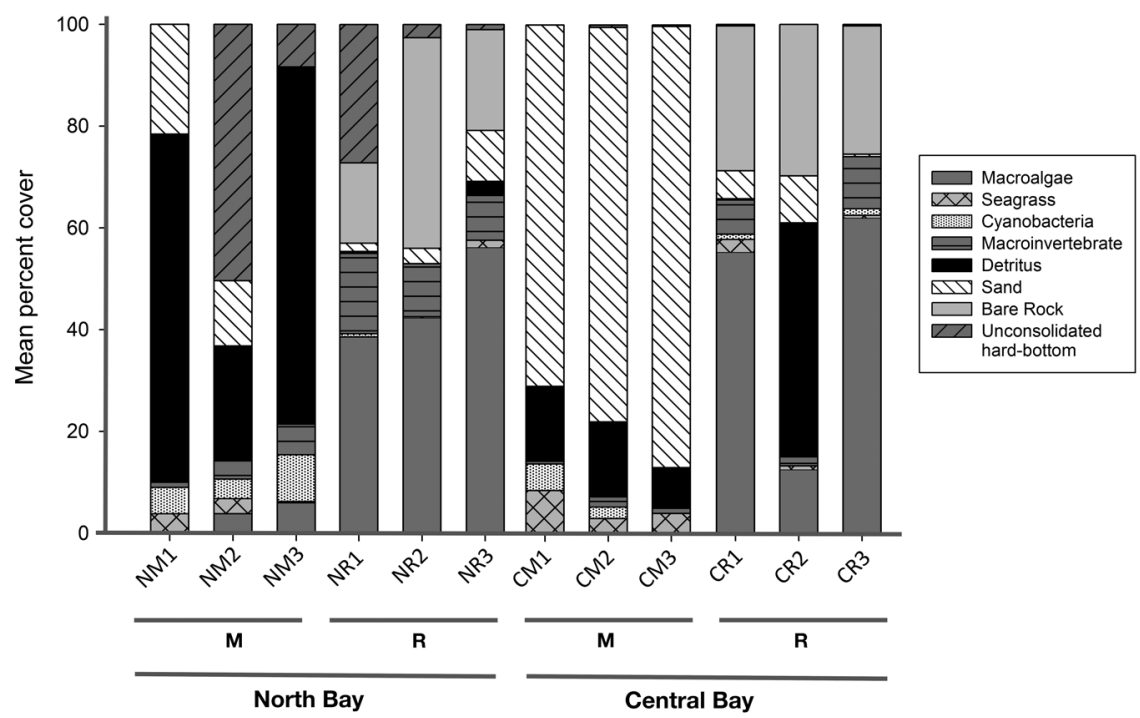

Figure 5. Benthic percent cover by habitat type and area of Biscayne Bay. Site codes contain the following information: Bay Area: $\mathrm{N}=$ north sites, $\mathrm{C}=$ central sites. Habitat type: $\mathrm{M}=$ mangrove, $\mathrm{R}=$ riprap-mangrove. See Figure 1 for site locations.

of more mobile species and provide refuge for large fish schools. Additionally, many of the mangrove sites were part of established mangrove forests with higher canopies and overhanging branches providing shade, which has been shown to be an important factor in attracting juvenile coral reef fish (Cocheret de la Morinière et al. 2004). Physical properties inherent to mangrove trees such as prop roots and overhanging branches are likely essential components of nursery habitat for juvenile fish (Nagelkerken et al. 2000a, Faunce and Layman 2009).

Mangrove restorations with riprap are characterized by much steeper slopes and the boulders are stacked in a way that creates crevices and small, but numerous, interstitial spaces (Markley et al. 1992). Species forming large schools (e.g., 1000+ individuals), like SWC fishes (i.e., Atherinopsidae and Clupeidae), may be precluded from this habitat by the small size of the refuge space between rocks compared to large, open spaces in between mangrove prop roots, making riprap an unsuitable habitat. Indeed, other than one riprap-mangrove site, NR3, SWC fishes were not observed in restored sites. Other reef-associated species may be attracted to the hard, more reeflike, structure provided by the riprap in these restored mangrove habitats. Shading from trees behind riprap is either absent or severely reduced because canopy height is shorter (approximately 2-5 $\mathrm{m}$ ) and the potential for overhanging branches is lower relative to more established intact mangroves, with some canopy heights exceeding $10 \mathrm{~m}$ (Fig. 2). Additionally, more reef-associated piscivores (e.g., snapper, jacks) were observed at the riprap-mangrove sites in the northern bay. If the higher relative abundance of piscivores at these sites results in an increased risk for juvenile fish, this could alter the nursery value of the riprap-mangrove sites.

In addition to differences in physical structure, differences in benthic composition among the two habitat types may drive differences in fish assemblages. Macroalgae was common in riprap-mangrove sites, while either absent or in low abundance in 
mangroves, which may be due to reduction of light availability from mangrove shade (Granek and Ruttenberg 2008). Macroalgae cover along riprap-mangrove shorelines may be an important food source for herbivores and could explain the high abundance of herbivorous fishes relative to mangrove shorelines (see Online Appendix 3 for fish species at each site). Additionally, soft sediments in mangroves may harbor different prey communities than the unconsolidated hard bottom found among riprap-mangrove shorelines, which could drive further differences in community structure (Seitz et al. 2006). Our findings suggest that the differences in benthic cover should be an additional factor to assess when comparing mangrove restorations.

We observed clear differences in fish assemblages among riprap-mangrove sites between the two areas of the bay. A possible explanation for this is the close proximity of the north sites to Baker's Haulover inlet (Fig. 1). These sites likely experience more tidal exchange relative to central sites resulting in differences in physical and biotic factors (such as salinity) and increased settlement rates of incoming larval fishes, respectively (Miller et al. 1984). Sponaugle and Cowen (1996) found a similar pattern of reduced reef fish larval recruitment to central areas of Barbados relative to areas more exposed to open ocean. Salinity differences from freshwater input (i.e., canals) could be another important factor driving differences between riprap-mangrove shorelines between areas of the bay (Serafy et al. 2003). However, fish assemblages along mangrove shorelines appeared to have been unaffected by the location of the bay and were similar in both areas. If salinity effects were responsible for driving the differences in fish assemblages in riprap-mangrove habitats among areas of the bay, we might expect to see a similar trend among fishes in mangroves. Similarly, Serafy et al. (1997) suggested that even for mangrove fish species known to be tolerant of salinity stress, differences in habitat features, like bottom type, were likely more important in driving differences in abundance among areas of the bay. It is more likely that incoming larval fishes recruit to north riprap-mangrove shorelines given their close proximity to the ocean and suitability of the habitat. Connectivity between mangroves and offshore coral reefs should be considered when prioritizing sites for restoration.

The restored sites we surveyed were between 10-15 yrs old, and it is conceivable that associated fish communities will converge as the mangroves at the riprap-mangrove sites mature. However, it is possible that the presence of riprap may actually limit mangrove growth. Mangrove habitat naturally expands through a cycle of sediment retention by prop roots and the subsequent generation of shallow substrate for settling propagules (Field 1998, Nagelkerken et al. 2000a). Among riprap-mangrove restoration sites in Biscayne Bay, lateral prop root growth could be inhibited by the lack of soft sediment and water depth beyond the riprap margin. Indeed, none of the prop roots of mangroves at riprap sites were observed reaching the sediment (JR Peters, pers obs; see e.g., Fig. 2B). Living shoreline projects involving the restoration of other sedimentary habitats (e.g., saltmarsh) are incorporating designs that preserve the soft-sediment tidal boundaries and availability of vegetative structure to aquatic organisms (Currin et al 2010). In living shoreline sills surveyed by Currin et al. (2008), the low-profile breakwaters were installed several meters from shore allowing for expansion of marsh. Perhaps similar designs could be implemented in future mangrove restoration projects, where shoreline stabilization methods (e.g., addition of oyster shell, riprap, or reef balls) could create habitat-forming reefs seaward of mangrove plantings, while still allowing mangrove growth. 
Determining the function of installed living shorelines is essential to improve restoration strategies (Chapman and Blockley 2009, Browne and Chapman 2011, Scyphers et al. 2011, Fodrie et al. 2014, Layman et al. 2014). In the case of restored mangroves, it is unlikely that the reduced mangrove structure at the riprap-mangrove sites is able to support some services provided by intact, natural, mangrove forests such as nutrient cycling and carbon sequestration. Nevertheless, riprap-mangrove restoration projects do seem to provide some of the functions of natural mangrove shorelines in terms of provisioning fish habitat, and have the potential to enhance the value of degraded or developed shorelines.

\section{ACKNOWLEDGEMENTS}

We thank K Weisenborn and M Zapata for their assistance with fieldwork. We would also like to thank W Goldberg, Y Zhang, and three anonymous reviews for their edits and feedback on the manuscript. Funding for this research was provided by the Capt. Kevin Llorente memorial scholarship to JRP and a FIU Dissertation Year Fellowship and the National Socio-Environmental Synthesis Center (SESYNC) under funding received from the National Science Foundation DBI-1052875 to LAY. This research formed the basis for the undergraduate honors thesis for JR Peters at Florida International University.

\section{Literature Cited}

Able KW, Manderson JP, Studholme AL. 1998. The distribution of shallow water juvenile fishes in an urban estuary: the effects of manmande structures in the lower Hudson River. Estuaries. 21:731-744. http://dx.doi.org/10.2307/1353277

Airoldi L, Abbiati M, Beck MW, Hawkins SJ, Jonsson PR, Martin D, Moschella PS, Sundelöf A, Thompson RC, Åberg P. 2005. An ecological perspective on the deployment and design of low-crested and other hard coastal defense structures. Coast Eng. 52:1073-1087. http:// dx.doi.org/10.1016/j.coastaleng.2005.09.007

Alongi DM. 2002. Present state and future of the world's mangrove forests. Environ Conserv. 29:331-349. http://dx.doi.org/10.1017/S0376892902000231

Bacchiocchi F, Airoldi L. 2003. Distribution and dynamics of epibiota on hard structures for coastal protection. Estuar Coast Shelf Sci. 56:1157-1166. http://dx.doi.org/10.1016/ S0272-7714(02)00322-0

Braun-Blanquet J. 1932. Plant sociology (Transl. G. D. Fuller and H. S. Conrad). McGraw-Hill, New York. 539 p.

Browne MA, Chapman MG. 2011. Ecologically informed engineering reduces loss of intertidal biodiversity on artificial shorelines. Environ Sci Technol. 45:8204-8207. http://dx.doi. org/10.1021/es201924b

Bulleri F, Chapman MG. 2010. The introduction of coastal infrastructure as a driver of change in marine environments. J Appl Ecol. 47:26-35. http://dx.doi. org/10.1111/j.1365-2664.2009.01751.x

Chambers JR. 1991. Coastal degradation and fish population losses. In: Stroud R, editor. Stemming the tide of coastal fish habitat loss: national coalition for marine conservation. p. 45-51.

Chapman MG, Blockley DJ. 2009. Engineering novel habitats on urban infrastructure to increase intertidal biodiversity. Oecologia. 161:625-635. http://dx.doi.org/10.1007/ s00442-009-1393-y

Clarke KR. 1993. Non-parametric multivariate analyses of changes in community structure. Aust J Ecol. 18:117-143. http://dx.doi.org/10.1111/j.1442-9993.1993.tb00438.x 
Cocheret de la Morinière E, Nagelkerken I, van der Meij H, van der Velde G. 2004. What attracts juvenile coral reef fish to mangroves: habitat complexity or shade? Mar Biol. 144(1):139_ 145. http://dx.doi.org/10.1007/s00227-003-1167-8

Currin CA, Delano PC, Valdes-Weaver LM. 2008. Utilization of a citizen monitoring protocol to assess the structure and function of natural and stabilizing fringing salt marshes in North Carolina. Wetlands Ecol Manage. 16:97-118. http://dx.doi.org/10.1007/s11273-007-9059-1

Currin CA, Chappell WS, Deaton A. 2010. Developing alternative shoreline armoring strategies: the living shoreline approach in North Carolina. In: Shipman H, Dethier MN, Gelfenbaum G, Fresh KL, Dinicola RS, editors. 2010, Puget Sound shorelines and the impacts of armoring - proceedings of a state of the science workshop, May 2009: US Geological Survey Scientific Investigations Report 2010-5254. p. 91-102.

Douglass SL, Pickel BH. 1999. The tide doesn't go out anymore - the effect of bulkheads on urban shorelines. Shore Beach. 67:19-25.

Faunce CH, Layman CA. 2009. Sources of variation that affect perceived nursery function of mangroves. In: Ecological Connectivity among Tropical Coastal Ecosystems, Springer. p. 401-421.

Faunce CH, Serafy JE. 2006. Mangroves as fish habitat: 50 years of field studies. Mar Ecol Prog Ser. 318:1-18. http://dx.doi.org/10.3354/meps318001

Field CB. 1998. Rehabilitation of mangrove ecosystems: an overview. Mar Pollut Bull. 37:383392. http://dx.doi.org/10.1016/S0025-326X(99)00106-X

Fodrie FJ, Rodriguez AB, Baillie CJ, Brodeur MC, Coleman SE, Gittman RK, Keller DA, Kenworthy MD, Poray AK, Ridge JT, et al. 2014. Classic paradigms in a novel environment: inserting food web and productivity lessons from rocky shores and saltmarshes into biogenic reef restoration. J Appl Ecol. 51:1314-1325. http://dx.doi.org/10.1111/1365-2664.12276

Froese R, Pauly D. 2000. Fishbase 2000: concepts, design and data sources. ICLARM, Los Baños, Laguna, Philippines. $344 \mathrm{p}$.

Grabowski JH, Peterson CH. 2007. Restoring oyster reefs to recover ecosystem services. In: Cuddington K, Byers JE, Wilson WG, Hastings A, editors. Ecosystem engineers, plants to protists. Elsevier Academic Press, Burlington, MA. p. 281-298.

Granek EF, Ruttenberg BI. 2007. Protective capacity of mangroves during tropical storms: a case study from "Wilma" and "Gamma" in Belize. Mar Ecol Prog Ser. 343:101-105. http:// dx.doi.org/10.3354/meps07141

Granek EF, Ruttenberg BI. 2008. Changes in biotic and abiotic processes following mangrove clearing. Estuar Coast Shelf Sci. 80:555-562. http://dx.doi.org/10.1016/j.ecss.2008.09.012

Harlem PW. 1979. Aerial photographic interpretation of historical changes in northern Biscayne Bay, Florida: 1925-1976. MSc Thesis. University of Miami, Coral Gables, Florida. $152 \mathrm{p}$.

Humann P. 1993. Reef coral identification: Florida, Caribbean, Bahamas, New World Publications, Jacksonville, Florida. $252 \mathrm{p}$.

Humann P. 1994. Reef fish identification: Florida, Caribbean, Bahamas, New World Press, Jacksonville, Florida. 396 p.

Jackson JBC, Kirby MX, Berger WH, Bjorndal KA, Botsford LW, Bourque BJ, Bradbury RH, Cooke R, Erlandson J, Estes JA, et al. 2001. Historical overfishing and the recent collapse of coastal ecosystems. Science. 293:629-637. http://dx.doi.org/10.1126/science.1059199

Kellogg ML, Cornwell JC, Owens MS, Paynter KT. 2013. Denitrification and nutrient assimilation on a restored oyster reef. Mar Ecol Prog Ser. 480:1-19. http://dx.doi.org/10.3354/ meps10331

Kentula ME. 2000. Perspectives on setting success criteria for wetland restoration. Ecol Eng. 15:199-209. http://dx.doi.org/10.1016/S0925-8574(00)00076-8

Layman CA, Jud ZR, Archer SK, Riera D. 2014. Provision of ecosystem services by artificial structures in a highly impacted estuary. Environ Res Lett. 9:044009. http://dx.doi. org/10.1088/1748-9326/9/4/044009 
Lewis RR. 2005. Ecological engineering for successful management and restoration of mangrove forests. Ecol Eng. 24:403-418. http://dx.doi.org/10.1016/j.ecoleng.2004.10.003

Littler DS, Littler MM. 2000. Caribbean reef plants: an identification guide to the reef plants of the Caribbean, Bahamas, Florida and Gulf of Mexico. Offshore Graphics, Inc. Washington, DC. 542 p.

Littler DS, Littler MM, Bucher KE, Norris JN. 1989. Marine plants of the Caribbean, a field guide from Florida to Brazil. Smithsonian Institution Press. 272 p.

Markely S, Milano GR, Calas E. 1992. Biscayne Bay restoration and enhancement program shoreline and habitat enhancement guide. In: Proceedings $19^{\text {th }}$ Annual Conference on Wetlands Restoration and Creation. Hillsborough Community College, Tampa, Florida. p. $111-120$.

Milano GR. 1999. Restoration of coastal wetlands in southeastern Florida. Wetland J. 11:15-24.

Milano GR, Hammerschlag N, Barimo J, Serafy JE. 2007. Restoring essential fish habitat in southeast Florida: mangrove and seagrass habitat design components and success monitoring. Bull Mar Sci. 80(3):928-929.

Miller JM, Reed JP, Pietrafesa LJ. 1984. Patterns, mechanisms, and approaches to the study of migrations of estuarine-dependent fish larvae and juveniles. In: McCleave JD, Arnold GP, Dodson JJ, Neill WH, editors. Mechanisms of migration in fishes. Plenum, New York. p. 209-225.

Moberg F, Rönnbäck P. 2003. Ecosystem services of the tropical seascape: interactions, substitutions and restoration. Ocean Coast Manage. 46(1):27-46. http://dx.doi.org/10.1016/ S0964-5691(02)00119-9

Mumby PJ, Edwards AJ, Arias-Gonzalez JE, Lindeman KC, Blackwell PG, Gall A, Gorczynska MI, Harborne AR, Pescod CL, Renken H, et al. 2004. Mangroves enhance the biomass of coral reef fish communities in the Caribbean. Nature. 427:533-536. http://dx.doi. org/10.1038/nature02286

Nagelkerken I, Dorenbosch M, Verberk WCEP, Cocheret de la Morinière E, van der Velde G. 2000. Importance of shallow-water biotopes of a Caribbean bay for juvenile coral reef fishes: patterns in biotope association, community structure and spatial distribution. Mar Ecol Prog Ser. 202:175-192. http://dx.doi.org/10.3354/meps202175

Nagelkerken I, Blaber SJM, Bouillon S, Green P, Haywood M, Kirton LG, Meynecke JO, Pawlik J, Penrose HM, Sasekumar A, et al. 2008. The habitat function of mangroves for terrestrial and marine fauna: a review. Aquat Bot. 89:155-185. http://dx.doi.org/10.1016/j. aquabot.2007.12.007

Odum WE, McIvor CC, Smith TJ. 1982. The ecology of the mangroves of South Florida: a community profile. Fish and Wildlife Service, Office of Biological Services, Washington DC, FWS/OBS-81/24. $144 \mathrm{p}$.

Peterson CH, Grabowski JH, Powers SP. 2003. Estimated enhancement of fish production resulting from restoring oyster reef habitat: quantitative valuation. Mar Ecol Prog Ser. 264:249-264. http://dx.doi.org/10.3354/meps264249

Peterson MS, Comyns BH, Hendon JR, Bond PJ, Duff GA. 2000. Habitat use by early life-history stages of fishes and crustaceans along a changing estuarine landscape. Wetlands Ecol Manage. 8:209-219. http://dx.doi.org/10.1023/A:1008452805584

Pilkey OH, Wright W. 1998. Sea-walls vs. Beaches. J Coast Res. 4:41-64.

Randall JE. 1967. Food Habits of Reef Fishes of the West Indies. Stud Trop Oceanogr. 5:665-847.

Scyphers SB, Powers SP, Heck KL, Byron D. 2011. Oyster reefs as natural breakwaters mitigate shoreline loss and facilitate fisheries. PLoS ONE. 6(8):e22396. http://dx.doi.org/10.1371/ journal.pone.0022396

Seitz RD, Lipcius RN, Olmstead NH, Seebo MS, Lambert DM. 2006. Influence of shallowwater habitats and shoreline development on abundance, biomass, and diversity of benthic prey and predators in Chesapeake Bay. Mar Ecol Prog Ser. 326.11-27. 
Serafy JE, Lindeman KC, Hopkins TE, Ault JS. 1997. Effects of freshwater canal discharge on fish assemblages in a subtropical bay: field and laboratory observations. Mar Ecol Prog Ser. 160:161-172. http://dx.doi.org/10.3354/meps160161

Serafy JE, Faunce CH, Lorenz JJ. 2003. Mangrove shoreline fishes of Biscayne Bay, Florida. Bull Mar Sci. 72:161-180.

Sponaugle S, Cowen RK. 1996. Nearshore patterns of coral reef fish larval supply to Barbados, West Indies. Mar Ecol Prog Ser. 133:13-28. http://dx.doi.org/10.3354/meps133013

Thayer GW, Colby DR, Hettler WF. 1987. Utilization of the red mangrove prop root habitat by fishes in south Florida. Mar Ecol Prog Ser. 35:25-38. http://dx.doi.org/10.3354/meps035025

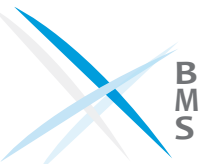


